\title{
Refleksi Atas Pemisahan Pemilu Nasional dan Pemilu Local
}

\author{
Roni Sulistyanto Luhukay \\ Fakultas Hukum Universitas Widya Mataram \\ Dalem Mangkubumen KT III/237 Kadipaten Kraton Daerah Istimewah Yogyakarta \\ Correspondence email: roni.luhukay@yahoo.com
}

\begin{abstract}
Abstrak. Penyelengaraan pemilihan umum di laksanakan secara serentak di Indonesia sebagai bagian dalam mensukseskan demokrasi berbagai permasalah hukum muncul mulai dari pada masa jabatan pejabat public yang belum akan berakhir pada saat pelaksanaan pesta demokrasi serentak di laknakan. Penelitian ini mengunakan metode yuridis normative di laksanakan duna menjawab Urgensi pemisahan pemilu nasional dan daerah dalam Penyelenggaraan pemilu lima kotak, dapat memambah beban kerja dan berpotensi dapat menghilangkan nyawa petugas kpps selain itu bukan hanya masalah manajemen penyelenggaraan, melainkan juga relevansinya dengan sistem pemerintahan, dan kemurnian hak pilih, desain keserentakan yang ada berdampak terhadap tidak optimalnya pelaksanaan hak pilih dan tidak terjaminnya proses penyelenggaraan pemilu sesuai asas jujur dan adil. Untukitu memahami Masalah pergulatan pemilihan serentak terjadi setelah pelaksanaan serentakpada memakan banyak korban dengan system lima kotak akan tetapi potensi jika tidak dilaksankan secara serentak akan berakibat pula kepada lemahnya posisi presiden untuk menyelaraskan agenda pemerintahan serta agenda pembangunan di karenakan Kepala daerah sebagai perpanjangan tangan pemerintah pusat, sekaligus sebagai penyelenggara otonomi daerah untuk tujuan pembangunan nasional, akan menghadapi perubahan konfigurasi politik.
\end{abstract}

Kata Kunci: Refleksi, Pemilu, Nasional, Local

Abstract. The holding of general elections is held simultaneously in Indonesia as part of the success of democracy. Various legal problems arise from the tenure of public officials which will not end when the implementation of a democratic party simultaneously is carried out. This research uses the normative juridical method which is carried out in response to the urgency of separating national and regional elections in the implementation of a five-box election, can increase the workload and can potentially eliminate the lives of Kpps officers besides that it is not only a matter of management management, but also its relevance to the government system and purity. Voting rights, the existing concurrency design impact on the non-optimal implementation of voting rights and the insecurity of the election process according to the principles of honesty and fairness. To understand that, the problem of simultaneous election struggles occurs after the simultaneous implementation of consuming many victims with a five-box system but the potential if it is not carried out simultaneously will also result in the weakness of the president's position to align the government agenda and development agenda because the regional head is an extension of the central government, at the same time as the organizer of regional autonomy for the purpose of national development, will face changes in the political configuration.

Keywords: reflection, Election, National, Local

\section{PENDAHULUAN}

Kedaulatan berada di tangan rakyak merupakn konsep negara demokrasi di Indonesia halini di pertegas dalam Pasal 1 ayat (2) UUD 1945, "Kedaulatan berada di tangan rakyat dan dilaksanakan menurut Undang-Undang Dasar NRI 1945"; untuk itu dalam menjalankan fungsi demokrasi yang memberikan kekuasaan penuh untuk menentukan suatu negara. Dengan kata lain pemerintahan demokrasi di tangan rakyat yang mengandung arti tiga hal yang pertama ; pemerintahan dari rakyat (goverment of the people), kedua pemerintahan oleh rakyat (goverment by the people), ketiga pemerintahan untuk rakyat (goverment for the people) tiga hal ini yang merupakan tolak ukur umum dalam satu pemerintahan yang demokratis. ${ }^{1}$ Berdasarkan halini lah melahirkan Pasal 22E ayat (1) UUD 1945, menjelaskan "Pemilihan umum dilaksanakan secara langsung, umum, bebas, rahasia, jujur, dan adil setiap llima tahun sekali"; selanjutnya Pasal 18 ayat (3) UUD 1945, "Pemerintahan daerah provinsi, daerah kabupaten, dan kota memiliki Dewan Perwakilan Rakyat Daerah yang anggota-anggotanya dipilih melalui pemilihan umum" dan Pasal 18 ayat (4) UUD 1945, "Gubernur, Bupati, dan Walikota masing-masing sebagai kepala pemerintah daerah provinsi kabupaten dan kota dipilih secara demokratis";

Pemilihan umum (pemilu) merupakan mekanisme demokrasi untuk memutuskan penggantian pemerintah di mana rakyat dapat menyalur hak politiknya secara bebas dan aman. Pemilu harus di laksanakan secara teratur serta kompetisi yang terbuka dan sederajat di antara partai-partai politik. Melalui pemilihan umum rakyat memilih wakilnya untuk duduk dalam parlemen dalam struktur pemerintahan. Penting demokrasi yang perlu mendapat perhatian dalam pembangunan demokrasi adalah pemilihan umum dan partai politik. Partai politik memiliki peran yang sangat

${ }^{1}$ Kamaruddin Azyumardi, "Demokrasi Hak Asasi Manusia Masyarakat Madani,” Penerbit Kencana, Jakarta 2008 Cetakan Ke 3, Hlm 40 
strategis terhadap proses demokratisasi. Selain sebagai struktur kelembagaan politik yang anggotanya bertujuan mendapatkan kekuasaan dan kedudukan politik, partai politik adalahn sebagai wadah bagi penampungan aspirasi rakyat. Peran tersebut merupakan implementasi nilai-nilai demokrasi, yaitu keterlibatan masyarakat untuk melakukan kontrol terhadap penyelenggaraan negara melali partai politik melalui partai-partai itulah segala aspirasi rakyat yang beraneka ragam dapat di salurkan secara teratur. ${ }^{2}$ Pemilihan umum selanjutnya di sebut pemilu merupakan sarana pelaksanaan kedaulatan rakyat yang di selanggarakan secara langsung, jujur dan adil dalam Negara Kesatuan Republik Indonesia tahun $1945 .^{3}$ Penyelenggaraan pemilihan umum di laksanakan secara lansung jujur dan adil setiap lima tahun sekali. ${ }^{4}$

Bagi Negara demokrasi modern, pemilihan umum (pemilu) merupakan merupakan mekanisme utama yang harus ada dalam tahapan penyelenggaran Negara dan pembentukan pemeritahan. Pemilu dipandang sebagai bentuk paling nyata dari kedaulatan yang berada di tangan rakyat serta wujud paling kongkrit partisipasi rakyat dan penyelenggarraaan Negara. Oleh karena itu, system dan penyelenggaraan pemilu selalu menjadiperhatian utama. Melalui penataan system dan kualitas penyelenggaraan pemilu diharapkan pemerintahan dari, oleh, dan untuk rakyat benar-benar dapatdiwujudkan. ${ }^{5}$

Di era reformasi, system dan penyelenggaraan pemilu telah mengalami banyak perkembangan dan perubahan. Setiap pelaksanaanpemilu selalu memiliki undang-undang (UU) tersendiri sebagai dasar pelaksanaannnya. Saat ini para pembentuk UU juga tengah mempersiapkan UU yang akan menentukan system dan penyelenggaraan pemilu yang akan datang. ${ }^{6}$ Perbaikan system dan penyelenggaraan pemilu memang selalu di perlukan berkaca dari kelemahan dan kelebihan dari system dan penyelenggaraan pemilu yang lalu. Itu semua tentu dimaksudkan untuk meningkatkan kualitas pemilu, sekaligus meningkatkan kualitas demokrasi. Namun demikian, tentu perbaikan itu harus di lakukan sesuai dengan prinsip dasar dan mengarah pada nilai konstitusional.

System pemilu saat ini tidak luput dengan adanya permasalahan hukum sehingga adanya gugatan ke mahkama konstitusi yang berkaitan dengan Pasal 167 Ayat (3) Undang-Undang Nomor 7 Tahun 2017 tentang Pemilu dan Pasal 201 Ayat (7) UU Nomor 10 Tahun 2016 tentang Pilkada.

Putusan Mahkamah Konstitusi perkara 55/PUU-XVII/2019 yang dimohonkan Perkumpulan untuk Pemilu dan Demokrasi (Perludem). Uji materi diajukan terhadap keserentakan pemilu yang diatur dalam Pasal 167 Ayat (3) Undang-Undang Nomor 7 Tahun 2017 tentang Pemilu dan Pasal 201 Ayat (7) UU Nomor 10 Tahun 2016 tentang Pilkada. Mahkamah Konstitusi memberikan sejumlah opsi pemilihan serentak yang masih konstitusional, yakni ${ }^{7}$ :

a. Pemilihan umum serentak untuk memilih anggota DPR, DPD, presiden dan wakil presiden, dan pemilihan anggota DPRD.

b. Pemilihan umum serentak untuk memilih anggota DPR, DPD, presiden dan wakil presiden, gubernur, bupati/wali kota.

c. Pemilihan umum serentak untuk memilih anggota DPR, DPD, presiden dan wakil presiden, anggota DPRD, gubernur, dan bupati/wali kota.

d. Pemilihan umum serentak nasional untuk memilih anggota DPR, DPD, presiden dan wakil presiden, dan beberapa waktu setelahnya dilakukan pemilihan umum serentak lokal untuk memilih anggota DPRD provinsi, DPRD kab/kota, pemilihan gubernur, dan bupati/wali kota.

e. Pemilihan umum serentak nasional untuk memilih anggota DPR, DPD, presiden dan wakil presiden, dan beberapa waktu setelahnya dilaksanakan pemilu serentak provinsi untuk memilih anggota DPRD provinsi, gubernur, dan kemudian beberapa waktu setelahnya dilakukan pemilu serentak kabupaten/kota untuk memilih DPRD kabupaten/kota dan memilih bupati/wali kota.

f. Pilihan-pilihan lainnya sepanjang tetap menjaga sifat keserentakan pemilihan umum untuk memilih anggota DPR, DPD, serta presiden dan wakil presiden.

Dengan demikian pemilu serentak, dalam arti pemilu legislatif dan pemilu eksekutif diselenggarakan dalam waktu bersamaan, merupakan solusi strategis untuk menghindari terbentuknya pemerintahan terbelah. Namun dalam konteks politik Indonesia masalahnya belum selesai, sebab pada tingkat provinsi dan kabupaten/kota juga menggunakan sistem presidensial, di mana anggota DPRD provinsi dan DPRD kabupaten/kota maupun gubernur dan

\footnotetext{
2Janedjri M. Gaffar, ”Politik Hukum Pemilu”, Jakarta, Konstitusi pers, Cetakan Pertama, 2012, Hlm 36

${ }^{3}$ Anonim, Kumpulan Undang-Undang Pemilihan Umum, (Sekretariat Jendral Kepaniteraan Mahkama Konstitusi Republik Indonesia, Tahun 2008), Hlm. 3.

${ }^{4}$ Yasir Arafat, Undang-Undang Dasar Republik Indonesia, 1945 Amandemen, (Pertama Press), Hlm19.

${ }^{5}$ Janedjri M. Gaffar, Op.,Cit, Hlm 53

${ }^{6}$ Janedjri M. Gaffar, Ibid.,

7 Putusan Mahkamah Konstitusi perkara 55/PUU-XVII/2019 yang dimohonkan Perkumpulan untuk Pemilu dan Demokrasi (Perludem). Uji materi diajukan terhadap keserentakan pemilu yang diatur dalam Pasal 167 Ayat (3) Undang-Undang Nomor 7 Tahun 2017 tentang Pemilu dan Pasal 201 Ayat (7) UU Nomor 10 Tahun 2016
} 
wakil gubernur serta bupati dan wakil bupati/walikota dan wakil walikota sama-sama dipilih melalui pemilu. Di sinilah penyelenggaraan pemilu serentak perlu dibagi dua: pertama, pemilu nasional untuk memilih anggota DPR, DPD, serta presiden dan wakil presiden; kedua, pemilu daerah untuk memilih anggota DPRD dan kepala daerah. ${ }^{8}$

Lahirnya pertentangan di tengah masyarakat kontroversi dikarenakan putusan tersebut dianggap tidak mempertimbangan "Beban berat dari jabatan politik yang dipilih serta kompleksitasnya sebab meninggalnya petugas pada pemilu-pemilu legislatif sebelumnya, meski tak sebanyak Pemilu 2019. Ini menjadi catatan penting kegagalan system demokrasi yang menimbulkan korban jiwa sehingga berbagai upaya di lakukan antara lain sebagai berikut yang Pertama, penyatuan pemilu DPR, DPRD provinsi, dan DPRD kabupaten/kota pada waktu bersamaan. Kedua, manajemen teknis kepemiluan seperti surat suara yang besar dan banyak. Distribusinya yang di lapangan mengalami kendala keterlambatan atau kekurangan jumlah.

Dengan banyaknya adanya kendala kemanusian di tambah lagi bangsa Indonesia di perhadapkan dengan masalah pandemic covid 19 saat ini untuk itu Seyogyannya pemilu menjadi dua bagian. Pertama, pemilu serentak nasional, yang menyelenggarakan pemilu presiden-wakil presiden, DPR, dan DPD. Kedua, pemilu serentak lokal, yang menyelenggarakan pilkada dan DPRD.

Selain mampu mengurangi beban kerja penyelenggara pemilu, kehadiran pemilu serentak dengan desain nasional dan lokal bisa memperbaiki sistem pemerintahan presidensial. Hal ini merujuk pengalaman sejumlah negara Amerika Selatan dan teori ilmu politik. ${ }^{9}$ Hal ini dilaksanakan Tanpa harus mengamandemen konstitusi dan banyak undang-undang politik," Untuk itu pemilu serentak juga bisa menghasilkan partai politik atau koalisi mayoritas dan sistem kepartaian multipartai moderat. Dengan catatan, hanya ada kurang dari lima partai politik efektif di Parlemen.

Putusan Mahkamah Konstitusi (MK) menerima pemilu serentak. Namun, pemilu serentak didesain dengan lima jenis pemilu sekaligus. Dalam hal ini pemilu lima surat suara ini lebih tepat dipandang sebagai pemilu borongan, ketimbang pemilu serentak. belajar dari pemilu sebelumnya seyogyannya agar pemerintah Indonesia mengupayakan kembali desain pemilu serentak nasional dan lokal. tetap menjadi bahagian yang terpisah pada saat pandemic saaat ini. Pentingnya desain jangka pajang politik nasional sebagai acuan utama. Sebab, saatnya pematangan system politik melalui penerapan dan pengembangan hukum pemilu di lakukan secara konsisten. ${ }^{10}$

Konsistensi dalam hukum pemilu dapat menghasilkan Pertama, kebebasan suatu kegiatan pengembangan diri, memasyarakatkan tersedianya kondisi-kondisi tertentu. Kedua, prinsip kesamaan yang di pahami sebagai sah satu bentuk hak-hak sama yang utama terhadap kondisi-kondisi pengembangan diri. Ketiga, resiprositas (ketimbal balikan) dan kegiatan bersama berfungsi sebagai kondisi sosial yang membebaskan dan juga berimplikasi pada bentuk serta wilayah pembuatan keputusan yang demokrasi, Keempat, demokrasi dapat di terapkan di terapkan tidak saja di wilayah politik maupun wilayah ekonomi sosial. ${ }^{11}$

Selain itu, setelah lebih dari satu dasawarsa reformasi, sudah saatnnya terdapat satu sisem dan model penyelenggaraan pemilu yang di pandang tepat sesuai dengan konsitusi dan kondisi bangsa Indonesia. Memang, ada berbagai pilihan system dan mekanisme penyeenggaraan pemilu yang dapat di pilih. Tapi,sebagai bagian dari upaya konsolidasi demokrasi, tentu sudah saatnya pun perbaikan system dan penyelenggaaan pemilu juga di lakukan secara konsolidatif. Dengan demikian perubahan atau perbaiikan yang di lakukan untuk setiap pemilu memiliki kejelasan arah. Ia bukan perubahan atau pengantian system yang berbeda atau berseberangan, yang pada akhirnya akan menghambat proses konsolidasi demokrasi dan kelembagaan Negara. ${ }^{12}$ Hukum pemilu merupakan sebuah entitas yang sangat kompleks, yang mempunyai banyak aspek,dimensi,dan fase. ${ }^{13}$ Bila di ibaratkan benda ia bagaikan permata, yang tiap irisan dan sudutnya akan memberikan kesan berbeda bagi setiap orang yang melihat atau memandangnya. Berdasarkan lata belakang diatas dapat di Tarik suatu permasalahan hukum yang hendaknya di jewab dalam suatu hasil penelitian dan pembahasan anatinya yang meliputi:

1. Apa Urgensi pemisahan pemilu nasional dan pemilu local?

2. Bagaimana Refleksi dalam memaknai pemilihan umum serentak di Indonesia?.

\section{METODE}

${ }^{8}$ Secretariat Bersama kodifikasi undang undang pemilu, Policy Brief [04] Kodifikasi Undang-undang Pemilu Oleh Sekretariat Bersama Kodifikasi Undang-undang Pemilu,hlm 6

${ }^{9}$ Perkumpulan untuk Pemilu dan Demokrasi (Perludem) tak sepakat dengan wacana pemisahan pemilihan legislatif (pileg) dan pemilihan presiden (pilpres). Perludem lebih mendorong pemilu serentak nasional dan lokal dipisah. Perludem Lebih Setuju Pemilu Nasional Dan Lokal Dipisah, https://www.medcom.id/nasional/politik/1bvyr7gn-perludem-lebih-setuju-pemilu-nasionaldan-lokal-dipisah, dikses Pada Hari Kamis 24 September 2020, Pukul 15:30 Wib

${ }^{10}$ Janedjri M. Gaffar, "Politik Hukum Pemilu”, Jakarta, Konstitusi pers, Cetakan Pertama,2012, Hlm 28

${ }^{11}$ Caror C.Gould," Demokrasi Di Tinjau Kembali, ” Penerbit PT Lion Wacana, Jogyakarta Thn 1993, Hlm 77.

12 Ibid., Hlm 37

${ }^{13}$ Sri Soemantri Martosoewignjo,” Dasar-Dasar Politik Hukum,” Rajawali Pers, Jakarta 1991 , Cetakakan pertama, Hlm 
Penelitian ini merupakan penelitian hukum dengan menggunakan metode penelitian hukum normatif. Menurut Philipus M Hadjon dan Tatiek Sri Djatmiati penelitian hukum normatif beranjak dari hakekat keilmuan hukum ${ }^{14}$. Sejalan dengan itu Peter Mahmud Marzuki mengemukan Legal Research adalah penelitian hukum yang mengunakan pendekatan, pendekatan perundang - undangan (Statute Aprroach), pendekatan konseptual (Conceptual Approach $)^{15}$

Dalam pembahasan pertama penulis menjelaskan mengenai pendekatan perundang - undangan ( Statute Aprroach ), dalam metode ini penulis perlu memahami hierarki, dan asas - asas dalam peraturan perundang undangan. Menurut Pasal 1 angka 2 Undang - Undang No. 12 Tahun 2011, peraturan perundang - undangan adalah peraturan tertulis yang memuat norma hukum yang mengikat secara umum dan dibentuk atau ditetapkan oleh lembaga Negara atau pejabat yang berwenang melalui prosedur yang ditetapkan dalam peraturan perundang - undangan. Dari pengertian tersebut, secara singkat dapat dikatakan bahwa yang dimaksud sebagai statute berupa legislasi dan regulasi. Jika demikian, pendekatan peraturan perundang - undangan adalah pendekatan dengan menggunakan legislasi dan regulasi. ${ }^{16}$

Pembahasan kedua penulis menjelaskan mengenai pendekatan konseptual (Conceptual Aprroach), pendekatan konseptual dilakukan manakala peneliti tidak beranjak dari aturan hukum yang ada. Hal itu dilakukan karena memang belum atau tidak ada aturan hukum untuk masalah yang dihadapi. Dalam membangun konsep hukum dengan beranjak dari pandangan - pandangan dan doktrin - doktrin yang berkembang didalam ilmu hukum. ${ }^{17}$.

\section{HASIL DAN PEMBAHASAN}

\section{Urgensi pemisahan pemilu nasional dan pemilu local}

Dasar Konstitusi Negara Kesatuan Republik Indonesia merupakan dasar yang dapat memberikan gambaran sejalan dengan itu K.C Wheare F.B.A berpendapat bahwa konstitusi di pakai untuk mengambarkan selurus sistem yang ada dalam suatu negara ${ }^{18}$, untuk itu berbagai regulasi peraturan dalam suatu pemerintahan menjalankan fungsi demokrasi diatur dalam konstitusi pasal 22 E UUD NRI tahun 1945 yang mengatur khusus tentang tentang pemilihan anggota DPR,DPD, DPRD serta presiden dan wakil presiden. Kesepakan demokratis mengenai pemilu dengan maksud agar bersifat fleksibel. ${ }^{19}$ Berdasarkan hal inilah lahirlah undang undang pemilu yang melahirkan pelaksanaan pemilu serentak di Indonesia, berbagai kalangan berpendapat lahirnya kebijakan pelaksanaan pemilu serenta dalam pesta demokrasi ini sangat berdampat terhadap meningkatnya beban kerja KPU, serta lemahnya isu pesta demokrasi di daerah karena adanya keserentakan pemilu nasional untuk itu adanya urgen di dahulukan untuk pemisahan penyelenggaraan pemilu nasional dan local.

Urgenitas pemisahan pemilu nasional dan local ini lahir setelah adanya pasal Pasal 167 ayat (3) UU Pemilu sepanjang frasa "pemungutan suara dilaksanakan secara serentak" dan Pasal 347 ayat (1) UU Pemilu, kemudian Pasal 3 ayat (1) UU Pilkada dinyatakan inkonstitusional bersyarat yakni sebagai berikut: dan Pasal 167 ayat (3) UU Pemilu Pemungutan suara dilaksanakan secara serentak pada hari libur atau hari yang diliburkan secara nasional. Dalam Frasa "pemungutan suara dilaksanakan secara serentak" dinyatakan bertentangan dengan UUD 1945 sepanjang tidak dimaknai "Pemungutan suara dilaksanakan secara serentak yang dibagi atas pemilu serentak nasional untuk memilih DPR, Presiden, dan DPD, dan dua tahun setelah pemilu serentak nasional dilaksanakan pemilu serentak daerah untuk memilih DPRD Provinsi, DPRD Kabupaten/Kota, Gubernur, Bupati, dan Walikota".

Selian itu juga muncul Pasal 347 ayat (1) UU Pemilu Pemungutan suara Pemilu diselenggarakan secara serentak.sepanjang tidak dimaknai "Pemungutan suara dilaksanakan secara serentak yang dibagi atas pemilu serentak nasional untuk memilih DPR, Presiden, dan DPD, dan dua tahun setelah pemilu serentak nasional dilaksanakan pemilu serentak daerah untuk memilih DPRD Provinsi, DPRD Kabupaten/Kota, Gubernur, Bupati, dan Walikota". dan di perkuat dengan Pasal 3 ayat (1) UU Pilkada Pemilihan dilaksanakan setiap 5 (lima) tahun sekali secara serentak di seluruh wilayah Negara Kesatuan Republik Indonesia. Sehingga sepanjang tidak dimaknai "Pemilihan Gubernur, Bupati, dan Walikota dilaksanakan serentak dengan DPRD Provinsi, DPRD Kabupaten/Kota melalui pemilu serentak daerah dua tahun setelah pelaksanaan pemilu serentak nasional".

Polemic muncul menginggat Pasal 201 ayat (7) dan Pasal 201 ayat (9) UU Pilkada dianggap bertentangan dengan UUD 1945 dan tidak memiliki kekuatan hukum mengikat. Selanjutnya Pasal 201 ayat (7) UU Pilkada yang menjelaskan Gubernur dan Wakil Gubernur, Bupati dan Wakil Bupati, serta Walikota dan Wakil Walikota hasil

${ }^{14}$ Philipus M Hadjon dan Tatiek Sri Djatmiati, Argumen Hukum, Surabaya, Gadjah Mada University Press, Cetakan Ke 7, 2016, hlm 3 .

${ }^{15}$ Johnny Ibrahim, Teori dan Metodologi Penelitian Hukum Normatif, Malang, Banyumedia, 2010, hlm 93

${ }^{16}$ Peter Mahmud Marzuki, Penelitian hukum, Edisi Revisi, Jakarta, Kencana, 2005, hlm 136.

${ }^{17}$ Ibid, hlm 177.

${ }^{18}$ K.C Wheare F.B.A, Modern Constitution, London, Oxford University Pers, 1975, hlm 1

${ }^{19}$ Haris Syamsuddin, "Partai, Pemilu, Dan Parlemen Era Reformasi”, Jakarta, Buku Obor, 2014, Cetakan Pertama., Hlm 
Pemilihan tahun 2020 menjabat sampai dengan tahun 2024. Selanjutnya Pasal 201 ayat (9) UU Pilkada Untuk mengisi kekosongan jabatan Gubernur dan Wakil Gubernur, Bupati dan Wakil Bupati, serta Walikota dan Wakil Walikota yang berakhir masa jabatannya tahun 2022 sebagaimana dimaksud pada ayat (3) dan yang berakhir masa jabatannya pada tahun 2023 sebagaimana dimaksud pada ayat (5), diangkat penjabat Gubernur, penjabat Bupati, dan penjabat Walikota sampai dengan terpilihnya Gubernur dan Wakil Gubernur, Bupati dan Wakil Bupati, serta Walikota dan Wakil Walikota melalui Pemilihan serentak nasional pada tahun 2024.

Untuk itu dalil dalil yang ada serta frasa dan norma tersebut bertentangan dengan bertentangan dengan Pasal 1 ayat (2), Pasal 4 ayat (1), Pasal 22E ayat (1), Pasal 18 ayat (3), dan Pasal 18 ayat (4) UUD 1945 sebagai berikut: Pasal 1 ayat (2) Kedaulatan berada di tangan rakyat dan dilaksanakan menurut Undang-Undang Dasar. Pasal 4 ayat (1) Presiden Republik Indonesia memegang kekuasaan pemerintahan menurut Undang-

Urgenitas pemisahan merupakan hak warga negara untuk memilih secara cerdas pada pemilihan umum serentak ini terkait dengan hak warga negara untuk membangun peta checks and balances dari pemerintahan presidensial dengan keyakinan sendiri. Untuk itu warga negara dapat mempertimbangkan sendiri mengenai penggunaan pilihan untuk memilih DPR dan DPRD yang berasal dari partai yang sama dengan calon presiden dan wakil presiden. Hanya dengan pemilihan umum serentak warga negara dapat menggunakan haknya memilih secara cerdas dan efisien"; serta adanya desain sistem pemilu serentak, akan memberikan efek satu sama lain antara keterpilihan presiden dan anggota DPR. Meskipun pengaruh itu akan tetap diserahkan kepada kemerdekaan dan kebebasan ${ }^{20}$.

Mengacuh pada sebuah sebuah desain pemilu yang merupakan sesuatu yang memiliki pengaruh signifikan terhadap peta checks and balances, terutama terkait dengan efektivitas sistem presidensil di Indonesia. Efektifitas di dalam sistem presidensil ini tentu saja ditujukan untuk memberikan penguatan terhadap posisi presiden sebagai pemegang kekuasaan dengan menjalankannya sebagaimana diatur di dalam UUD 1945. Untuk itu desain pelaksanaan pemilu lima kotak akan berakibat pula kepada lemahnya posisi presiden untuk menyelaraskan agenda pemerintahan serta agenda pembangunan, karena pemilihan kepala daerah dengan DPRD tidak diserentakkan. Kepala daerah sebagai perpanjangan tangan pemerintah pusat, sekaligus sebagai penyelenggara otonomi daerah untuk tujuan pembangunan nasional, akan menghadapi perubahan konfigurasi politik yang berubah-ubah ketika pemilihan kepala daerah tidak diserentakkan dengan pemilihan anggota DPRD, baik di tingkat provinsi, maupun pada tingkat kabupaten/kota.

Penyelenggaran pemilu serentak dengan lima kotak suara secara sekaligus, telah secara nyata menimbulkan kerumitan bagi pemilih di dalam memberikan pilihan politiknya. Terkait hal ini akan kami jelaskan di dalam rangkaian argumentasi berikutnya, yang dibuktikan dengan penelitian yang dilakukan oleh Lembaga Ilmu Pengetahuan Indonesia. Inilah yang membuat pemilu serentak lima kotak menjadi irasional bagi pemilih, karena mesti menghadapi surat suara yang banyak, jumlah calon yang banyak, sehingga mustahil pula kita akan berharap pemilih akan rasional dalam memberikan pilihan politiknya memberatkan bagi pemilih, pemilu serentak lima kotak juga telah menunjukkan bahwa penyelenggaraannya meningkatnya suara tidak sah, sehingga ini jelas merendahkan derajat keterwakilan pemilih di dalam sebuah proses pemilu. Terkait dengan kuantitas suara tidak sah.

Penyelengaraan Pemilu 2019 yang dilaksanakan secara serentak untuk memilih Presiden dan Wakil Presiden, anggota DPR, anggota DPD, anggota DPRD provinsi, dan anggota DPRD kabupaten/kota, dapat diketahui bahwa pemilu secara serentak dengan lima kota memiliki berbagai persoalan yang cukup serius, sehingga membutuhkan evaluasi. Persoalan tersebut tidak saja terkait manajemen dan teknis pelaksanaan, melainkan juga berhubungan dengan substansi pemilu, yaitu kemurnian hak pilih warga negara sebagai wujud konkrit kedaulatan rakyat yang ditegaskan dalam Pasal 1 ayat (2) UUD 1945. Selain itu muncul fakta fakta empiris yang menyatakan penyelenggaraan Pemilu Serentak 2019 memakan banyak korban penyelenggara pemilu, artinya desain penyelenggaraan Pemilu dengan 5 kotak seperti diinginkan oleh Pembentuk UUD 1945 sebagaimana menjadi salah satu dasar Mahkamah Konstitusi memutuskan mengabulkan permohonan dalam perkara Nomor 14/PUU-XI/2013 perlu diuji dan dipertimbangkan kembali konstitusionalitasnya dari sisi hak-hak konstitusional yang telah nyata-nyata terlanggar oleh karena itu perlu dipandang sebagai upaya evaluasi atas hasil uji coba design yang nyata-nyata malah memakan banyak korban jiwa ${ }^{21}$

${ }^{20}$ Sebuah desain pelaksanaan jadwal pemilu, adalah sesuatu yang memiliki pengaruh signifikan terhadap peta checks and balances, terutama terkait dengan efektivitas sistem presidensil di Indonesia. Efektifitas di dalam sistem presidensil ini tentu saja ditujukan untuk memberikan penguatan terhadap posisi presiden sebagai pemegang kekuasaan dengan menjalankannya sebagaimana diatur di dalam UUD 1945, dalam kerangka politik hukum di Indonesia, pemilihan gubernur, bupati, dan walikota dipilih secara langsung, serta tugas, fungsi, dan wewenang dari gubernur, bupati, dan walikota di dalam kerangka otonomi daerah, mengharuskan adanya irisan kepentingan dan kewenangan dalam fungsi cheks and balances dengan DPRD di daerah masingmasing. Dalam konteks ini, menurut Pemohon, hubungan dua lembaga, antara DRPD dan kepala daerah, tidaklah bisa dilepaskan dari proses pemilihannya, khususnya jadwal pelaksanaan pemilu serentaknya di kutip dalam Putusan Mahkama Konstitusi Nomor 55/PUU-XVII/2019.

${ }^{21}$ Penyelenggaraan pemilu lima kotak, telah membuat pelaksanaan teknis pemungutan dan penghitungan suara menjadi sangat panjang dan melelahkan. Berdasarkan data Kementerian Kesehatan per tanggal 16 Mei 2019, jumlah petugas KPPS yang 
Jika dirunut ke belakang, desain pelaksanaan pemilu serentak 2019 merupakan tindak lanjut Putusan MK Nomor 14/PUU-XI/2013. Dalam putusan pengujian UU Nomor 42 Tahun 2008 tersebut, MK menegaskan bahwa penyelenggaraan Pilpres yang tidak bersamaan dengan penyelenggaraan anggota legislatif adalah bertentangan dengan Pasal 22E ayat (2) UUD 1945. Putusan itu didasarkan atas tiga pertimbangan pokok, yaitu kaitan antara sistem pemilihan dan sistem pemerintahan presidensial, original intent pembentukan UUD 1945, efektifitas dan efisiensi penyelenggaraan pemilu, serta hak memilih warga negara secara cerdas. .

Adapun pertimbangan terkait original intent Pasal 22E ayat (2) UUD 1945 justru mendapat krtikan di masyarakat mengingat. Alasan menyerentakkan Pilpres dengan pemilu seluruh anggota legislatif, baik pusat maupun daerah akan menyebabkan beratnya beban penyelenggaraan dan juga akan menyebabkan pemilih tidak dapat memberikan hak suaranya secara rasional. Kritikan ini ternyata memang menjadi kenyataan dalam Pemilu serentak 2019, di mana penyelenggara menanggung beban manajemen penyelenggaraan yang berat, sehingga muncul persoalan seperti tidak begitu siapnya logistik pemilu, banyaknya surat suara yang tidak sah, dan yang lebih berat adalah meninggalnya lebih dari 550 orang penyelenggara pemilu di tingkat bawah. Terlepas adanya laporan dari Kementerian Kesehatan bahwa faktor yang menyebabkan banyaknya petugas yang meninggal adalah karena stroke, gagal jantung dan alasan kesehatan lainnya, namun beban kerja penyelenggaraan pemilu ikut berkonstribusi terhadap munculnya masalah tersebut.

Pemisahan penyelenggaraan pemilu nasional dari penyelenggaraan pemilu daerah jauh lebih menjamin demokrasi daripada pemilu serentak. Hal ini dapat dibuktikan dengan alasan berikut:

a) Rakyat/pemilih dapat menuntut akuntabilitas peserta pemilu dua kali dalam lima tahun;

b) urusan pemerintahan daerah mendapat kesempatan yang sama menjadi isu publik dengan urusan pemerintahan nasional tetapi dalam waktu yang berbeda untuk menjadi bahan diskusi diantara peserta pemilu dan diantara pemilih; ${ }^{22}$

c) peserta pemilu akan dapat fokus pada isu urusan pemerintahan nasional pada pemilu nasional dan pada isu urusan pemerintahan daerah pada pemilu daerah sehingga mereka dapat bersaing baik dalam menawarkan alternatif program maupun alternaif calon kepada pemilih. Selain itu peserta pemilu juga diwajibkan mempertanggungjawabkan kinerjanya kepada konstituen pada kedua jenis pemilu tersebut;

d) media massa juga akan meliput dan memberitakan kegiatan pemilu daerah pada penyelenggaraan pemilu penyelenggara urusan pemerintahan daerah;

e) bahan informasi yang harus dicari, didengar, dan diolah pemilih tidak akan terlalu banyak karena isu urusan pemerintahan nasional dipisahkan forum pemilunya dari isu urusan pemerintahan daerah sehingga pemilih akan dapat mengambil keputusan secara bebas;

f) tugas proses pemungutan dan penghitungan suara yang harus dilaksanakan oleh KPPS menjadi lebih ringan, yaitu tiga jenis pemilu pada pemilu nasional, dan empat jenis pemilu pada pemilu daerah. Penyelesaian tugas ini tidak hanya akan dengan pasti dapat diselesaikan dalam satu hari tetapi juga lama waktu yang diperlukan untuk menyelesaikan tugas tersebut masih manusiawi; ${ }^{23}$

meninggal dunia adalah 527 jiwa dan tercatat 11.239 orang sakit setelah menyelenggarakan tugasnya sebagai anggota KPPS. Hal ini membuktikan, secara manajemen pelaksanaan, khususnya untuk proses pemungutan dan penghitungan suara yang mesti selesai pada hari yang sama (setelah ada putusan Mahkamah diberi waktu tambahan sampai pukul 12.00 waktu setempat sehari setelah pemungutan suara) adalah sesutu pekerjaan yang mesti diselesaikan di luar batas kemampuan daya tahan tubuh manusia. Hal ini bersesuaian pula dengan Putusan Mahkamah Nomor 31/PUU-XVI/2018, bahwa rasionalitas di dalam menentukan pilihan pengaturan manajemen pemilu, merupakan isu konstitusionalitas yang berkaitan langsung dengan pemenuhan asas penyelenggaraan pemilu, dikutib dalam Putusan Mahkama Konstitusi Nomor 55/PUU-XVII/2019.

22 Pemerintahan daerah merupakan salah satu lembaga yang mendapatkan tugas dan kewenangan dari UUD 1945. Pasal 18 UUD 1945 berikut ini memperlihatkan apa saja yang menjadi tugas dan kewenangan pemerintahan daerah. Pasal 18 UUD 1945 :

1) Negara Kesatuan Republik Indonesia dibagi atas daerah-daerah provinsi dan daerah provinsi itu dibagi atas kabupaten dan kota, yang tiap-tiap provinsi, kabupaten, dan kota itu mempunyai pemerintahan daerah, yang diatur dengan undang-undang.

2) Pemerintah daerah provinsi, daerah kabupaten, dan kota mengatur dan mengurus sendiri urusan pemerintahan menurut asas otonomi dan tugas pembantuan.

3) Pemerintahan daerah provinsi, daerah kabupaten, dan kota memiliki Dewan Perwakilan Rakyat Daerah yang anggotaanggotanya dipilih melalui pemilihan umum.

4) Gubernur, Bupati, dan Walikota masing-masing sebagai kepala pemerintah daerah provinsi, kabupaten dan kota dipilih secara demokratis.

5) Pemerintahan daerah menjalankan otonomi seluas-luasnya, kecuali urusan pemerintahan yang oleh undang-undang ditentukan sebagai urusan pemerintahan pusat.

6) Pemerintahan daerah berhak menetapkan peraturan daerah dan peraturan-peraturan lain untuk melaksanakan otonomi dan tugas pembantuan.

7) Susunan dan tata cara penyelenggaraan pemerintahan daerah diatur dalam undang-undang

23 Aparat Sipil Negara (ASN) memiliki jam kerja mulai jam 08.00 pagi sampai dengan jam 16.00 (8 jam). Pegawai di Amerika Serikat bekerja dari jam 09.00 sampai dengan jam 17.00 (from nine to five) alias 8 jam juga 
Desain keserentakan pemilu yang menyerentakkan pilpres dengan pemilu seluruh anggota legislatif (pusat dan daerah dan sistem proporsional terbuka) ternyata memiliki masalah. Masalah tersebut tidak saja terkait manajemen penyelenggaraan, melainkan juga relevansinya dengan sistem pemerintahan, dan kemurnian hak pilih sebagai bagian dari hak konstitusional warga negara yang mesti dilindungi. Ketika desain keserentakan yang ada berdampak terhadap tidak optimalnya pelaksanaan hak pilih dan tidak terjaminnya proses penyelenggaraan pemilu sesuai asas jujur dan adil, maka realitas tersebut tentunya patut menjadi dasar bagi Mahkamah untuk memperbaiki dan/atau mungkin menyempurnakan pendiriannya terkait desain keserentakan pemilu, khususnya pendirian yang didasarkan pada original intent Pasal 22E ayat (2) UUD 1945. Pertimbangan agar hak pilih dapat dilaksanakan sesuai prinsip pemilu yang jujur dan adil Pasal 22E ayat (1) UUD 1945 tentunya harus lebih diutamakan dibandingkan pertimbangan original intent norma Pasal 22E ayat (2). Pemenuhan standar penyelenggaraan pemilu yang mampu menjamin hak pilih warga negara diberikan secara rasional dalam pemilu yang jujur dan adil tersebut secara tidak langsung juga akan memperkuat sistem presidensial. Untuk itu kesempatan warga negara untuk mengenal kandidat secara baik dan menentukan pilihan secara logis akan turut menentukan kualitas kekuatan politik yang mengisi kekuasaan eksekutif dan legislatif pusat sesuai yang dikehendaki konstitusi. Oleh karena itu, koreksi atas desain keserentakan pemilu memang perlu dilakukan dalam melaksankan mekanisme demokrasi. ${ }^{24}$ untuk itu sistem pemilihan umum serentak pemilu yang tidak mampu mencapai tujuan itu hanyakan menjadi mekanisme pemberian legitimasi bagi pemegan kekuasaan negara. pemilu demikian adalah pemilu yang kehilangan ruh demokrasi. ${ }^{25}$ Untuk pelaksaaan keserentakan dianggap tidak rasional dan mengandung obesitas hukum yang artinya konsep ini terlalu berlebihan dengan tidak mempertimbnagakan beben kerja dan konsidi di lapangan serta berpotensi melahirkan kekacouan hukum atau konflik dalam kehidupan masyarakat dan tindakan sewenang-wenang. ${ }^{26}$

\section{Refleksi dalam memaknai pemilihan umum serentak di Indonesia.}

Menurut UU pemilu, pemilihan umum di laksanakan untuk memilih pemimpin negara daerah ataupun badan legislative yang ada di daerah mapun dipusat yang pemilihannya dilaksanakan secara langsung dalam Negara Kesatuan Republik Indonesia Berdasarkan Pancasila dan Undang-Undang Dasar Negara Republik Indonesia Tahun 1945. ${ }^{27}$ Dalam menjalankan fungsi pemilihan Lembaga KPU di tugaskan dalam menjalankan funsi demokrasi guna mensukseskan fungsi demokrasi ini KPU di harapkan menembatkan posisinya sebagai Lembaga independen ${ }^{28}$

Berhasil tidaknya pemilu bisa dilihat dari sisi proses dan hasil. Proses pemilu dapat dikatakan sukses bila asas luber dan jurdil benar-benar terwujud dalam setiap pelaksanaan tahapan pemilu. Di sini semua peraturan perundangundang dan prosedur pelaksanaan tahapan benar-benar terimplementasi dengan baik dan benar; setiap terjadi pelanggaran, pelaku mendapatkan sanksi sesuai ketentuan ${ }^{29}$.Konsep pemilihan umum yang di laksankan di Indonesia dengan Pemilu Serentak yang meruapakan sebuah Solusi Lijphart (1994) berpendapat bahwa pemilu serentak (concurrent election) merupakan solusi untuk mengatasi divided government. Pemilu serentak adalah pemilu parlemen dan pemilu presiden yang diselenggarakan bersama dalam satu hari H pemilihan. Kajian Pyane dkk. (2002) menunjukkan, pemilu serentak tidak hanya berhasil menyederhanakan sistem kepartaian di parlemen, tetapi juga berkecenderungan membentuk pemerintahan kongruen, di mana presiden terpilih berasal dari partai atau koalisi partai yang menguasai mayoritas parlemen. Di sini terdapat dua faktor penyebab terbentuknya koalisi sebelum pemilu dan terjadinya coattail effeck.

Pemilu serentak mendorong terbentuknya pemerintahan kongruen karena partai-partai terpaksa menggalang koalisi lebih dini sebelum pemilu. Pemilu serentak menimbulkan coattail effect yaitu kecenderungan pemilihan presiden dan keterpilihannya berpengaruh terhadap pemilihan dan keterpilihan anggota parlemen. Jelasnya, keterpilihan Calon Presiden A mempengaruhi keterpilihan calon anggota parlemen dari partai atau koalisi partai yang mengajukan Calon Presiden A. Dalam pemilu serentak, pemilih akan memilih presiden sekaligus partai atau koalisi partai pendukung presiden. Pemilih merasa memilih presiden lebih penting daripada memilih anggota parlemen.

${ }^{24}$ Putusan Mahkama Konstitusi Nomor 55/PUU-XVII/2019 mengenai Pasal 22E ayat (1) UUD 1945, yakni pemilihan umum dilaksanakan secara langsung, umum, bebas, rahasia, jujur, dan adil setiap lima tahun sekali haruslah menjadi basis bertindak, untuk menentukan desain sistem pelaksanaan pemilu di Indonesia. Setiap desain pelaksanaan pemilu, mulai sistem pelaksaaan, pelaksanaan setiap tahapan pemilu, hingga sampai kepada penetapan hasil pemilu mesti dilaksanakan secara langsung, umum, bebas rahasia, jujur, dan adil

${ }^{25}$ Janedjri M. Gaffar, Op. Cit., Hlm. 44.

${ }^{26}$ Roni Sulistyanto Luhukay, Karakteristik Tanggung Gugat Perusahaan Terhadap Lingkungan Dalam Menciptakan Kesejateraan Rakyat, Junal Meta Yuridis Universitas PGRI Semarang, Volume 2 No 1 Tahun 2009, Hlm 26.

${ }^{27}$ Anonim, Undang-Undang Pemilu (Pemilihan Umum); Undang-Undang Republik Indonesia Nomor 15 Tahun 2011, Tentang Penyelenggaraan Pemilihan Umum, (Yogyakarta: Pustaka Mahardika), Hlm 9

${ }^{28}$ Muchamad Isnaeni Ramahdan, “Kompediun Pemilian Kepala Daerah”, Jakarta Thn 2009, Hlm 61

29 Secretariat Bersama kodifikasi undang undang pemilu, Policy Brief [04] Kodifikasi Undang-undang Pemilu Oleh Sekretariat Bersama Kodifikasi Undang-undang Pemilu, hlm 1 
Pemilu Serentak untuk lima jenis pemilu, yaitu pemilu anggota Dewan Perwakilan Rakyat (DPR), pemilu anggota Dewan Perwakilan Daerah (DPD), pemilu Presiden dan Wakil Presiden, pemilu anggota Dew an Perwakilan Rakyat Daerah Provinsi, dan pemilu anggota Dewan Perwakilan Rakyat Daerah Kabupaten/Kota, dapat dilihat dari dua dimensi, yaitu pemilu demokratik dan efisiensi. Prinsip yang mendasari, dan yang menjadi ukuran bagi kelima jenis pemilu tersebut bukan efisiensi melainkan pemilu demokratik. You can have election between having democracy but you cannot have democracy without election. Pernyataan ini menunjukkan adanya dua tipe pemilu, yaitu pemilu tanpa demokrasi yang sering disebut authoritarian election; dan pemilu yang demokratis. Berdasarkan tujuh asas pemilu yang disebutkankan pada pasal 22e ayat (1) uud 1945, yaitu langsung, umum, bebas, rahasia, jujur dan adil, dan periodik (lima tahun sekali), maka kelima jenis pemilu yang dirumuskan pada Pasal 22E ayat (2) tidak bisa lain haruslah demokratis.

Pemilu Demokratik berkaitan dengan tujuan dan cara. Karena demokrasi menjadi tujuan, maka cara menyelenggarakan pemilu juga harus demokratis. Karena itu pemilu serentak dapat ditinjau dari segi efektivitas (Effective) dan efisiensi (Efficiency). Perbedaan efektivitas dan efisiensi yang sangat tepat adalah berikut ini: Being effective is about doing the right things, while being efficient is about doing things right.

Pemilu serentak untuk kelima jenis pemilu akan dapat dikategorikan efektif bila mencapai tujuan (efek) yang ditetapkan. Doing the right things berarti melaksanakan sesuatu sesuai dengan tujuannya baik cara maupun tujuan yang hendak dicapai keduanya harus the right things. Kelima jenis pemilu tersebut harus dilaksanakan sesuai dengan tujuannya. Pemilu serentak untuk kelima jenis pemilu akan dapat dikategorikan efisien bila cara atau metode yang digunakan tepat. Cara atau metode yang tepat (doing things right) adalah efisien dari segi waktu, tenaga dan dana. Manfaat dan keuntungan (benefit) harus lebih besar daripada ongkos (cost) yang dikeluarkan. Manfaat dari suatu cara jauh melebihi ongkos yang dikeluarkan, maka cara apapun dapat ditempuh. The end justify the means. Karena kelima jenis pemilu tersebut dilaksanakan secara serentak pada hari dan tanggal yang sama, maka penyelenggaraan kelima jenis pemilu tersebut niscaya akan sangat efisien, setidak-tidaknya dari segi jumlah anggaran yang dikeluarkan. Karena kelima jenis pemilu dan pemilu demokratik merupakan substansi konstitusi, maka menurut hemat saya, pemilu serentak untuk kelima jenis pemilu tersebut harus ditinjau dari dimensi efektivitas (Effective), bukan dari dimensi efisiensi (Efficiency). Para ahli ilmu politik, baik perbandingan politik maupun administrasi publik, banyak memperdebatkan isu demokrasi dan efisiensi. Akan tetapi tampaknya terdapat semacam konsensus bahwa demokrasi harus mendahului efisiensi. Bila dihadapkan pada dua pilihan tersebut niscaya pilihan akan jatuh pada demokrasi. Akan tetapi karena efisiensi juga penting, sering disebut asas manfaat, maka bila terdapat sejumlah alternatif pilihan, maka efisiensi akan juga diadopsi sepanjang sejalan dengan prinsip demokrasi. Pada Pasal 33 ayat (4) UUD 1945 terdapat ungkapan: "efisiensi harus berkeadilan." Karena itu Pasal 22E ayat (2) UUD 1945 hendaknya juga dibaca dan dipahami pertama dari segi demokrasi baru kemudian efisiensi. Ditinjau dari segi effisiensi, pemilu serentak merupakan keharusan. Akan tetapi dari segi pemilu demokrasi, pemilu serentak ternyata tidak semuanya sejalan dengan demokrasi. ${ }^{30}$

Kejadian pada pemilu serentak yang diselenggarakan pada bulan April 2019 yang lalu dapat didiskripsikan satu per satu sebagai berikut.

1. waktu yang tersedia bagi KPU untuk merencanakan, melaksanakan, dan mengendalikan pelaksanaan semua tahapan pemilu dapat dikatakan sangat memadai; dan pembuatan seluruh peraturan pelaksanaan setiap tahapan, dan pengadaan, dan distribusi seluruh alat kelengkapan pemungutan dan penghitungan suara dapat dilaksanakan dalam waktu yang tersedia. Akan tetapi volume pekerjaan KPU memang sangat besar; KPU harus melaksanakan pekerjaan dua tahun dalam satu tahun.

2. partai politik peserta pemilu melaksanakan empat kegiatan sekaligus: membangun kesepakatan dengan partai lain tentang pasangan calon Presiden dan Wakil Presiden; mengidentifikasi, menyeleksi, dan menentukan daftar calon anggota DPR, DPRD Provinsi, dan DPRD Kabupaten/Kota; merumuskan visi, misi dan program partai sebagai

${ }^{30}$ Ramlan Subekti yang di kutib dalam Putusan Mahkama Konstitusi Nomor 55/PUU-XVII/2019 terkaid dengan hak warga negara untuk memilih secara cerdas pada pemilihan umum serentak ini terkait dengan hak warga negara untuk membangun peta checks and balances dari pemerintahan presidensial dengan keyakinan sendiri. Untuk itu warga negara dapat mempertimbangkan sendiri mengenai penggunaan pilihan untuk memilih DPR dan DPRD yang berasal dari partai yang sama dengan calon presiden dan wakil presiden. Hanya dengan pemilihan umum serentak warga negara dapat menggunakan haknya memilih secara cerdas dan efisien serta pemilu lima kotak akan berakibat pula kepada lemahnya posisi presiden untuk menyelaraskan agenda pemerintahan serta agenda pembangunan, karena pemilihan kepala daerah dengan DPRD tidak diserentakkan. Kepala daerah sebagai perpanjangan tangan pemerintah pusat, sekaligus sebagai penyelenggara otonomi daerah untuk tujuan pembangunan nasional, akan menghadapi perubahan konfigurasi politik yang berubah-ubah ketika pemilihan kepala daerah tidak diserentakkan dengan pemilihan anggota DPRD, baik di tingkat provinsi, maupun pada tingkat kabupaten/kota serta problematika Pasal 22E ayat (2) UUD 1945, yakni pemilihan anggota Dewan Perwakilan Rakyat, Dewan Perwakilan Daerah, Presiden dan Waki Presiden, dan Dewan Perwakilan Daerah. 
materi kampanye; menyusun strategi kampanye dan mencari dana kampanye pemilu; dan melaksanakan kampanye pemilu baik untuk pemilu Presiden dan Wakil Presiden maupun pemilu anggota DPR dan DPRD.

3. pelaksanaan kampanye pemilu lebih didominasi oleh: (a) kampanye pemilu Presiden dan Wakil Presiden daripada kampanye pemilu anggota DPR, DPD, dan DPRD; (b) kampanye pemilu untuk isu urusan pemerintahan nasional oleh kedua pasangan calon presiden daripada isu urusan pemerintahan daerah (otonomi daerah); dan (c) persaingan antar calon dari partai yang sama di daerah pemilihan yang sama daripada persaingan antar partai politik peserta pemilu. Singkat kata, program atau rencana kebijakan yang hendak diwujudkan oleh partai politik peserta pemilu sama sekali tidak jelas.

4. waktu yang tersedia bagi pemilih dalam mencari dan mengolah informasi, dan memberikan suara (mencoblos lima peserta pemilu dan calon) di TPS berlangsung relatif lancar dan tepat waktu kedua pasangan calon presiden ternyata mampu membangkitkan minat dan partisipasi Pemilih. Partisipasi pemilih (voting turnout) pada Pemilu Serentak 2019 mencapai 81\% lebih. Karena para calon anggota DPR dan DPRD yang melakukankampanye pemilu (persaingan antar calon dari partai yang sama di dapil yang sama), maka visi, misi, dan program partai tampaknya tidak digunakan sebagai materi kampanye. Para calon cenderung mengambil jalan pintas dan pragmatis dalam mempengaruhi pemilih, yaitu dengan pertukaran materi dengan suara (vote buying). Materi kampanye pemilu cenderung diganti dengan pemberian materi (uang dan sembako). Pelaksanaan pemungutan suara berlangsung relatif lancar karena kebanyakan pemilih sudah siap dengan nomor urut partai dan nomor urut calon yang akan dicoblos. Kesiapan itu bukan berasal dari kemampuan mengolah (memilah, menilai, dan memilih) informasi tentang berbagai alternatif peserta pemilu dan rencana kebijakan yang ditawarkan melainkan berasal dari kehendak calon yang telah "membeli" suara pemilih.

5. persoalan justru muncul dalam proses penghitungan suara di TPS. Penghitungan suara satu per satu dari lima jenis pemilu, baik partai politik maupun nama calon secara transparan (di depan para saksi, pengawas TPS, pemantau, pemilih dan warga masyarakat) niscaya memakan waktu yang panjang.30 Perlu dikemukakan di sini bahwa Indonesia merupakan satu-satunya negara demokrasi di dunia yang melaksanakan pemungutan dan penghitungan suara sekaligus di setiap TPS secara terbuka.31 Praktek ini merupakan the best practice dari pemilu demokratik. Waktu dan tenaga yang diperlukan sangat lama dan karena itu sangat melelahkan tidak hanya proses penghitungan suara tetapi juga dalam menyusun berita acara dan sertifikat hasil perhitungan suara (C1) untuk kelima jenis pemilu, dan menyusun salinan berita acara dan salinan sertifikat hasil perhitungan suara untuk kelima jenis pemilu yang akan diberikan kepada saksi pemilu baik yang hadir maupun tidak hadir (16 saksi partai peserta pemilu nasional dikalikan tiga, 2 saksi pasangan calon presiden, dan puluhan saksi calon anggota DPD, dan panitia pelaksana (PPK, PPS, dan pertinggal di KPPS). Tidak diketahui berapa orang dari 7 anggota KPPS yang mampu menyusun berita acara dan sertifikat hasil perhitungan suara. Semua berita acara dan sertifikat ini harus basah (ditulis dengan tangan, tidak boleh difotocopy).

6. pemilu serentak lima tahun sekali akan menyebabkan ketua dan anggota KPU, KPU Provinsi, KPU Kabupaten/Kota, dan para pegawai KPU; ketua dan anggota Bawaslu, Provinsi, Kabupaten/Kota dan para pegawai Bawaslu; dan ketua dan anggota DKPP menganggur selama sisa masa jabatannya, tetapi menerima uang kehormatan setelah pemilu serentak. Pemilu serentak lima tahun sekali tidak hanya merupakan pemborosan sumber daya manusia tetapi juga pemborosan dana.

7. proses penyelesaian sengketa hasil pemilu presiden dan wakil presiden oleh Mahkamah Konstitusi lebih banyak diberitakan oleh media massa daripada proses penyelesaian sengketa hasil pemilu legislatif. Akan tetapi proses penyelesaian sengketa hasil pemilu legislatif sesungguhnya jauh lebih kompleks daripada sengketa hasil pemilu presiden dan wakil presiden walaupun tidak banyak diberitakan oleh media massa. Setidak-tidaknya dari segi jumlah permohonan mencapai 330 perkara DPR/DPRD, tetapi yang diregister hanya sebanyak 250, dan 10 perkara DPD, dan semuanya diregister. Semua perkara ini harus diselesaikan oleh Mahkamah Konstitusi dalam waktu dua bulan. Saya tidak dapat membayangkan bagaimana Mahkamah Konstitusi menyelesaikan begitu banyak sengketa pemilu serentak.

8. akuntabilitas peserta pemilu dapat dituntut secara efektif oleh pemilih hanya sekali dalam lima tahun. Sebaliknya peserta pemilu hanya wajib mempertanggungjawabkan kinerjanya lima tahun sekali. Lima tahun bukan jangka waktu pendek sehingga pemilih justru sudah lupa apa yang dikerjakan dan yang tidak dikerjakan oleh peserta pemilu. Salah satu kelebihan bentuk pemerintahan parlementer dibandingkan dengan bentuk pemerintahan presidensial adalah akuntabilitas penyelenggara negara hasil pemilu. Akuntabilitas eksekutif dapat dituntut setiap waktu oleh pemilih melalui anggota parlemen (terutama oposisi) sedangkan akuntabilitas kepala eksekutif (presiden) hanya dituntut pada akhir masa jabatannya. Akan tetapi kelemahan bentuk pemerintahan presidensial ini dapat diperbaiki dengan jalan menyelenggarakan pemilu untuk penyelenggara pemerintahan nasional secara terpisah (selang 30 bulan) dari penyelenggaraan pemilu untuk penyelenggara pemerintahan daerah. Pasal 18 ayat (5) UUD 1945 dirumuskan ketentuan berikut: Pemerintahan daerah menjalankan otonomi seluas-luasnya, kecuali urusan pemerintahan yang oleh undang-undang ditentukan sebagai urusan Pemerintahan Pusat. Dari pasal ini 
dapat disimpulkan urusan pemerintahan dibedakan menjadi dua kategori, yaitu urusan pemerintahan daerah dan urusan pemerintahan pusat (nasional). ${ }^{31}$

Dengan pemisahan pemilu nasional dari pemilu daerah seperti ini, rakyat pemilih akan dapat menuntut akuntabilitas peserta pemilu daerah pada pemilu nasional, dan 30 bulan kemudian dapat menuntut akuntabilitas peserta pemilu nasional pada pemilu daerah.

Putusan menyerentakkan pilpres dengan pemilu legislatif merupakan putusan yang sudah tepat dari aspek pemurnian dan penguatan sistem presidensial. Hanya saja, dari aspek manajamen penyelenggaraan dan upaya menjaga kemurnian hak pilih dalam pemilu, desain keserentakan memang memiliki masalah tersendiri. Ketika desain keserentakan pemilu 2019 harus dievaluasi, maka desain waktu penyelenggaraan pemilu tetap harus berada dalam kerangka memperkuat sistem presidensial. Pada saat yang sama, juga harus mempertimbangkan aspek manajemen penyelenggaraan dan kemudahan pemilih dalam menentukan pilihannya secara rasional. Dengan demikian, evaluasi keserentakan pemilu tidak harus dijawab dengan kembali pada desain waktu penyelenggaraan yang diterapkan sebelumnya. Sebab, desain tersebut jelas tidak memiliki konstribusi lebih untuk penguatan sistem presidensial.

Berdasarkan kerangka pikir demikian, maka keserentakan pilpres dengan pemilu anggota DPR dan DPD seharusnya tetap dipertahankan. Sebab, keserentakan itulah yang secara nyata berdampak terhadap penguatan sistem presidensial sebagamana dimaksud MK dalam Putusan Nomor 14/PUU-XI/2013. Selain itu, mekanisme check and balances yang diharapkan terjadi adalah antara kekuasaan pemerintahan negara yang dipegang Presiden dengan kekuasaan legislatif yang dipegang DPR. Adapun keserentakan pilpres dengan pemilu anggota DPRD provinsi dan DPRD kabupaten/kota hampir tidak memiliki dampak terhadap perimbangan kekuasaan presiden dengan lembaga legislatif. Sebab, hubungan kekuasaan presiden dengan kekuasaan DPRD bukanlah hubungan yang bersifat horizontal, melainkan vertikal. Oleh karena itu, alasan penguatan sistem presidensial dengan menyerentakkan pilpres dengan pemilu anggota DPRD sesungguhnya tidaklah relevan. Untuk itu pada Prinsipnya pengunaan rasionalitas dlam pemilu serentak sebagai bagian untuk mencegah terjadinya isu di local hal ini di karenakan sebagai negara kesatuan maka kewenanga pusat lebih dapat menjawab permasalahan yang ada di daerah artinya penerapan pemilu serentak mengandung makna, ketepatan atau pelaksanaan sesuai dengan tujuan dan sarana yang di gunakan untuk mencapai tujuan $^{32}$.

Dalam membangun Paradigma menegakan keadilan subtantif yang diguna oleh suatu regulasi yang berkaitan dengan procedural dengan tidak membuka peluang keadilan menempatkan MK penentu akan tetapi proses dan nilai demokrasi yang masih berlangsung masih di warnai pembajakan.. untuk itu Mahkamah Konstitusi tidak hanya memperlias keadilan, akan tetapi juga memeperkuat demokrasi yang berlangsung. ${ }^{33}$

Masalah pergulatan pemilihan serentak terjadi setelah pelaksanaan serentakpada tahun 2019 memakan banyak korban dengan system lima kotak yang memambah beban kerja petugas akan tetapi apabila tidak di serentakan pemilihan umum akan berakibat pula kepada lemahnya posisi presiden untuk menyelaraskan agenda pemerintahan serta agenda pembangunan, karena pemilihan kepala daerah dengan DPRD tidak diserentakkan. Kepala daerah sebagai perpanjangan tangan pemerintah pusat, sekaligus sebagai penyelenggara otonomi daerah untuk tujuan pembangunan nasional, akan menghadapi perubahan konfigurasi politik yang berubah-ubah ketika pemilihan kepala daerah tidak diserentakkan dengan pemilihan anggota DPRD, baik di tingkat provinsi, maupun pada tingkat kabupaten/kota

\section{SIMPULAN}

1. Urgensi di laksankannya pemisahan pemilu nasional dan daerah adalah belum berakhirnya massa jabatan pejabat public jika di laksnakan pemilihan serentak serta Penyelenggaraan pemilu lima kotak, telah membuat pelaksanaan teknis pemungutan dan penghitungan suara menjadi sangat panjang dan melelahkan yang berpotensi dapat menghilangkan nyawa seperti halnya terjadi di tahun 2019. permasalahan lain muncul terkait bukan hanya masalah manajemen penyelenggaraan, melainkan juga relevansinya dengan sistem pemerintahan, dan kemurnian hak pilih sebagai bagian dari hak konstitusional warga negara yang mesti dilindungi. desain keserentakan yang ada berdampak terhadap tidak optimalnya pelaksanaan hak pilih dan tidak terjaminnya proses penyelenggaraan pemilu sesuai asas jujur dan adil. Penyelengaraan pemilu serentak seyogyannya di rubah dengan adanya pemisahan pemilu nasional dan local hal ini di kerenakan benyaknya pejabat public yang massa jabatannya belum akan berakhir

${ }^{31}$ Pemilu untuk memilih penyelenggara urusan pemerintahan daerah (DPRD dan kepala daerah baik provinsi maupun kabupaten/kota) harus dipisahkan dengan pemilu untuk memilih penyelenggara urusan pemerintahan nasional (DPR, DPD, dan Presiden). Karena Indonesia mengadopsi susunan negara kesatuan, maka pemilu nasional harus diselenggarakan lebih dahulu.

32 Roni Sulistyanto Luhukay, Abdul Kodir Jailani, Penataan Sistem Peraturan Perundang-Undangan Dalam Mendukung Pengutan Konstitusi Ekonomi Indonesia, Jurnal Jatiswara, Universitas Mataram Lombok, Volume 34 No 2 Juli 2019 , hlm 158.

33 Ahmad Sodiki, “Jurnal Konstitusi Implementasi Putusan MK Terhadap Sistem Pemilu Dan Demokrasi,” Jakarta, Jurnal Redaksi Konstitusi, 2011, Hlm.119. 
selain itu dengan pemilu lima kotak juga sangat menambah beban kerja penyelengaran pesta demokrasi yang dapat berpotensi membahayakan keselamatan seperti halnya terjadi di tahun 2019 untuk itu dengan adanya pemisahan pemilu secara nasional dan local merupakan Langkah revolusioner.

2. Masalah pergulatan pemilihan serentak terjadi setelah pelaksanaan serentakpada tahun 2019 memakan banyak korban dengan system lima kotak yang memambah beban kerja petugas akan tetapi apabila tidak di serentakan pemilihan umum akan berakibat pula kepada lemahnya posisi presiden untuk menyelaraskan agenda pemerintahan serta agenda pembangunan, karena pemilihan kepala daerah dengan DPRD tidak diserentakkan. Kepala daerah sebagai perpanjangan tangan pemerintah pusat, sekaligus sebagai penyelenggara otonomi daerah untuk tujuan pembangunan nasional, akan menghadapi perubahan konfigurasi politik yang berubah-ubah ketika pemilihan kepala daerah tidak diserentakkan dengan pemilihan anggota DPRD, baik di tingkat provinsi, maupun pada tingkat kabupaten/kota, Pelaksanaan Pemilu serentak sangat baik jika di terapkan akan tetapi di butuhkan kesiapan yang matang sehingga tidak akan muncul pergulatan seyogyannya pelaksanaan pesta demokrasi tidak hanya di laksanakan berdasrkan menyelaraskan agenda pemerintahan serta agenda pembangunan, karena pemilihan kepala daerah dengan DPRD di agendakan menjadi satu akan tetapi harus dapat melihat hal yag lain yang berkaitan dengan ekonomi social budaya di tambah dengan kondisi pandemic covid 19 yang di alami saat ini.

\section{DAFTAR PUSTAKA}

\section{Buku}

Anonim, Kumpulan Undang-Undang Pemilihan Umum, (Sekretariat Jendral Kepaniteraan Mahkama Konstitusi Republik Indonesia, Tahun 2008).

======, Undang-Undang Pemilu (Pemilihan Umum); Undang-Undang Republik Indonesia Nomor 15 Tahun 2011, Tentang Penyelenggaraan Pemilihan Umum, (Yogyakarta: Pustaka Mahardika)

Kamaruddin Azyumardi, "Demokrasi Hak Asasi Manusia Masyarakat Madani," Penerbit Kencana, Jakarta 2008 Cetakan Ke 3.

Janedjri M. Gaffar, "Politik Hukum Pemilu”, Jakarta, Konstitusi pers, Cetakan Pertama,2012.

Yasir Arafat, Undang-Undang Dasar Republik Indonesia, 1945 Amandemen , (Pertama Press).

K.C Wheare F.B.A, Modern Constitution, London, Oxford University Pers, 1975.

Caror C.Gould," Demokrasi Di Tinjau Kembali," Penerbit PT Lion Wacana, Jogyakarta Thn 1993

Sri Soemantri Martosoewignjo," Dasar-Dasar Politik Hukum," Rajawali Pers, Jakarta 1991 , Cetakakan pertama

Philipus M Hadjon dan Tatiek Sri Djatmiati, Argumen Hukum, Surabaya, Gadjah Mada University Press, Cetakan Ke 7, 2016

Johnny Ibrahim, Teori dan Metodologi Penelitian Hukum Normatif, Malang, Banyumedia, 2010

Peter Mahmud Marzuki, Penelitian hukum, Edisi Revisi, Jakarta, Kencana, 2005.

Haris Syamsuddin, "Partai, Pemilu, Dan Parlemen Era Reformasi”, Jakarta, Buku Obor, 2014, Cetakan Pertama.

Muchamad Isnaeni Ramahdan, “Kompediun Pemilian Kepala Daerah”, Jakarta Thn 2009.

\section{Jurnal}

Ahmad Sodiki, “Jurnal Konstitusi Implementasi Putusan MK Terhadap Sistem Pemilu Dan Demokrasi," Jakarta, Jurnal Redaksi Konstitusi, 2011

Roni Sulistyanto Luhukay, Karakteristik Tanggung Gugat Perusahaan Terhadap Lingkungan Dalam Menciptakan Kesejateraan Rakyat, Junal Meta Yuridis Universitas PGRI Semarang, Volume 2 No 1 Tahun 2009.

$===================$, Abdul Kodir Jailani, Penataan Sistem Peraturan Perundang-Undangan Dalam Mendukung Pengutan Konstitusi Ekonomi Indonesia, Jurnal Jatiswara, Universitas Mataram Lombok, Volume 34 No 2 Juli 2019.

\section{Lain lain}

Secretariat Bersama kodifikasi undang undang pemilu, Policy Brief [04] Kodifikasi Undang-undang Pemilu Oleh Sekretariat Bersama Kodifikasi Undang-undang Pemilu.

Ramlan Subekti yang di kutib dalam Putusan Mahkamah Konstitusi Nomor 55/PUU-XVII/2019

Putusan Mahkamah Konstitusi perkara 55/PUU-XVII/2019

Perkumpulan untuk Pemilu dan Demokrasi (Perludem) tak sepakat dengan wacana pemisahan pemilihan legislatif (pileg) dan pemilihan presiden (pilpres). Perludem lebih mendorong pemilu serentak nasional dan lokal dipisah. Perludem Lebih Setuju Pemilu Nasional Dan Lokal Dipisah, https://www.medcom.id/nasional/politik/1bvyr7gn-perludem-lebih-setuju-pemilu-nasional-dan-lokal-dipisah, dikses Pada Hari Kamis 24 September 2020, Pukul 15:30 Wib 